\title{
PENERAPAN METODE DISKUSI DAN BERCERITA DALAM AJARAN PUNARBHAWA SEBAGAI BAGIAN DARI SRADHA UNTUK MENINGKATKAN PRESTASI BELAJAR AGAMA HINDU DAN BUDI PEKERTI SISWA KELAS IV SEMESTER I SD NEGERI 4 TONJA TAHUN PELAJARAN 2016/2017
}

\author{
Oleh \\ Ni Luh Kusumawati \\ SD Negeri 4 Tonja \\ watikusuma945@gmail.com
}

\begin{abstract}
ABSTRAK
Penelitian ini dilaksanakan di SD Negeri 4 Tonja di Kelas IV Semester I yang prestasi belajar agama Hindu dan budi pekerti masih rendah. Tujuan penulisan penelitian tindakan kelas ini adalah untuk mengetahui apakah Penerapan Metode Diskusi Dan Bercerita Dalam Ajaran Punarbhawa Sebagai Bagian Dari Sradha dapat Meningkatkan Prestasi Belajar Agama Hindu Dan Budi Pekerti Siswa Kelas IV Semester I SD Negeri 4 TonjaTahun Pelajaran 2016/2017. Metode pengumpulan datanya adalah tes prestasi belajar. Metode analisis datanya adalah deskriptif. Hasil yang diperoleh dari penelitian ini adalah Penerapan Metode Diskusi Dan Bercerita Dalam Ajaran Punarbhawa Sebagai Bagian Dari Sradha Untuk Meningkatkan Prestasi Belajar Agama Hindu Dan Budi Pekerti Siswa Kelas IV Semester I SD Negeri 4 TonjaTahun Pelajaran 2016/2017 . Ini terbukti dari hasil yang diperoleh pada pada awalnya 63,23 dengan ketuntasan 48,89\% setelah diberikan tindakan pada siklus I meningkat menjadi 68,55 dengan ketuntasa 62,22 \% dan pada siklus II meningkat lagi menjadi 76,22 dengan ketuntasan 100\%. Kesimpulan yang diperoleh dari penelitian ini adalah Penerapan Metode Diskusi Dan Bercerita Dalam Ajaran Punarbhawa Sebagai Bagian Dari Sradha dapat Meningkatkan Prestasi Belajar Agama Hindu Dan Budi Pekerti Siswa Kelas IV Semester I SD Negeri 4 TonjaTahun Pelajaran 2016/2017
\end{abstract}

\section{Kata Kunci: Metode Diskusi, Bercerita, Prestasi Belajar, Ajaran Punarbawa}

\section{PENDAHULUAN}

Peranan Mata Pelajaran Pendidikan Agama Hindu di Sekolah Dasar cukup kompleks, di samping mengembangkan Pengetahuan Budi Pekerti yang diperlukan anak juga dimaksudkan untuk menguasai berbagai keterampilan yang dapat dimanfaatkan dalam kehidupannya kelak di kemudian hari. Pada usia SD tingkat pertumbuhan badan sedang mengalami perlambatan, sedangkan pertumbuhan mental mengalami masa kreatif dan kritisnya yang merupakan kesempatan anak mempelajari budi pekerti dan berfikir seluas-luasnya. Jika masa ini tidak dimanfaatkan sebaik-baiknya untuk melatih kemampuan mental anak, maka 
konsekuensinya menelantarkan salah satu masa keemasan yang dimiliki anak sepanjang usianya untuk berkembang secara optimal. Dalam proses pembelajaran yang berlangsung di kelas, untuk dapat mencapai tujuan yang maksimal seperti yang diharapkan harus terjadi komunikasi aktif antara guru selaku penyampai informasi dengan siswa sebagai penerima informasi atau pengetahuan. Komunikasi yang akan dijalin oleh guru selaku agen dalam pembelajaran harus dimulai dengan perencanaan yang baik, sehingga alur pembelajaran yang dilakukan dapat berjalan secara sistematis dan terarah. Seperti yang dinyatakan Hamzah B Uno (dalam Yamin dan Maisah, 2009: 123) bahwa istilah pembelajaran memiliki hakkat perencanaan atau perancangan (desain) sebagai upaya untuk membelajarkan siswa. Itulah sebabnya siswa-siswa tidak hanya berinteraksi dengan guru sebagai salah satu sumber belajar, tetapi mungkin berinteraksi dengan keseluruhan sumber belajar yang dipakai untuk mencapai tujuan pembelajaran yang diinginkan. Oleh karena itu, pembelajaran yang terjadi memusatkan perhatian pada bagaimana membelajarkan siswa dan bukan pada apa yang dipelajari siswa. Faktor-faktor yang disebutkan tersebut sangat berpengaruh terhadap pencapaian hasil tes yang diberikan pada anak kelas IV semester I SD Negeri 4 Tonja Tahun Pelajaran 2016/2017 ternyata baru mencapai nilai rata-rata 63,23 dengan prosentase ketuntasan belajar sebesar 48,89\%

Mengatasi kesenjangan antara harapan dengan kenyataan di lapangan,memotivasi peneliti sebagai guru Agama Hindu di kelas IV di SD Negeri 4 Tonja mengupayakan peningkatan prestasi belajar agama
Hindu dan Budi Pekerti dengan menerapkan dipilih metode diskusi dan bercerita karena dalam pelajaran agama hindu materinya berupa suatu proses yang berkelanjutan dan sulit dipelajari sendiri oleh siswa sehingga perlu dipelajari secara bertahap (selangkah demi selangkah) dengan bantuan langsung dari guru. Arends (dalam Trianto,2009:41) yang menyebutkan bahwa Model metode diskusi dan bercerita adalah salah satu pendekatan mengajar yang dirancang khusus untuk menunjang proses belajar siswa yang berkaitan dengan pengetahuan deklaratif dan pengetahuan prosedural yang terstruktur dengan baik yang dapat diajarkan dengan pola kegiatan yang bertahap, selangkah demi selangkah. Dengan tindakan yang seperti itu diharapkan prestasi belajar peserta didik akan dapat ditingkatkan.

\section{METODE}

Penelitian ini dilaksanakan di SD Negeri 4 Tonja Jalan Antasura 4X, Kecamatan Denpasar Utara. Subjek penelitian ini adalah semua Siswa kelas IV Semester I SD Negeri 4 Tonja tahun pelajaran 2016/2017. Objek penelitiannya adalah peningkatan prestasi belajar agama Hindu dan Budi Pekertisiswa kelas IV semester I SD Negeri 4 Tonja tahun pelajaran 2016/2017 dengan penerapan metode diskusi dan bercerita dalam ajaran Punarbhawa. Penelitian ini dilakukan dari bulan Juli sampai bulan Nopember 2016 Sebagai gambaran dari pelaksanaan penelitian. Cara yang dilakukan dalam mengumpulkan data hasil penelitian ini adalah tes prestasi belajar. Metode yang digunakan untuk menganalisis data hasil penelitian ini adalah metode 
deskriptif kuantitatif. Data kuantitatif dianalisis dengan mencari mean, median, modus.

\section{KAJIAN PUSTAKA \\ Model diskusi}

Diskusi kelompok kecil menurut I.G.A.K. Wardani dan Siti Julaeha (IDIK 4307: 22) menjelaskan bahwa diskusi kelompok keci adalah salah satu bentuk kegiatan pembelajaran yang penggunaannya cukup sering diperlukan dengan ciriciri: 1) melibatkan 3-9 orang peserta; 2) berlangsung dalam situasi tatap muka yang informal, artinya setiap anggoa dapat berkomunikasi langsung dengan anggota lainnya; 3) mempunyai tujuan yang dicapai dengan kerjasama antar anggota, serta 4) berlangsung menurut proses yang sistematis.

Menurut Paizaluddin dan Ermalinda (2012: 215) metode diskusi merupakan cara penyajian pelajaran dimana siswa dihadapkan kepada suatu masalah yang bisa berupa pernyataan atau pertanyaan yang bersifat problematik untuk dibahas dan dipecahkan bersama.

Metode diskusi merupakan
metode atau cara yang dapat
diupayakan untuk meningkatkan
kerjasama antarsiswa, saling
membantu, saling pengertian antara
mereka dengan memberi suatu
masalah untuk didiskusikan. Dalam
kegiatan tersebut mereka dapat saling
tukar pengalaman, saling tukar
informasi, sehingga semua siswa dapat
aktif dalam belajar.

Langkah -langkah dalam metode diskusi kelompok kecil
1. Anggota kelompok nya menjadi 3-4 kelompok kecil yang terdiri dari 3 atau 4 orang

2. Pemimpim agar mengkoordinir anggota kelompok nya agar diskusi kelompok kecil berjalan baik dan tepat waktu .

3. Pemimipin juga ikut membantu setiap kelompok kecil dalam menyelesaikan tugas yang diberikan oleh guru.

4. Tahap diskusi

Manfaat metode diskusi

a. Memupuk rasa toleransi yaitu setiap siswa saling menghargai terhadap pendapat yang dikemukakan oleh setiap siswa.

b. Memupuk kehidupan demokratis yaitu setiap siswa secara bebas dan bertanggungjawab terbiasa mengemukakan pendapat bertukar pikiran untuk mencapai tujuan pembelajaran yang diharapkan .

c. Mendorong pembelajaran secara aktif yaitu siswa dalam membahas suatu topic pembelajaran tidak selalu menerima dari guru .

d. Menumbuhkan kan rasa percaya diri yaitu dengan kebiasaan untuk beragumentasi yang dilakukan antar sesame teman dalam kelompok diskusi .

Kelebihan diskusi

- Dapat mengembangkan bakat kepemimpinan.

- Siswa lebih aktif Mengemukkan pendapat.

- Diskusi yang dilakukan dalam beberapa tahap membuat siswa lebih mengingat dan memahami apa yang telah mereka lakukan.

Kelemahan diskusi 
- Keberhasilan tergantung pada kemampuan siswa pemimpin

- Di butuhkan waktu yang banyak dalam metode diskusi.

\section{Metode Bercerita}

Winda Gunarti (2010: 5.3 5.7) menjelaskan bahwa metode bercerita adalah metode yang dilakukan seseorang untuk menyampaikan suatu pesan, informasi atau sebuah dongeng belaka yang bisa dilakukan secara lisan atau tertulis. Cara permainan cerita tersebut dapat dilakukan dengan menggunakan alat peraga atau tanpa alat peraga. Tujuan metode bercerita adalah mengembangkan kemampuan berbahasa, berfikir dengan bercerita, menanamkan pesan-pesan moral, kepekaan sosial emosional, melatih daya ingat, mengembangkan potensi kreatif melalui keragaman ide cerita. Bentuk-bentuknya adalah tanpa alat peraga dan dengan alat peraga.

Menurut pendapat diatas pengertian kedua metode tersebut adalah mengajak anak-anak untuk bercakap-cakap bagaimana menggunakan bahasa untuk menyampaikan suatu pesan, dalam melakukan pembelajaran, guru harus paham juga dengan perkembangan anak agar pembelajaran bisa terarah.

Guru juga harus banyak bercerita dan memberi penjelasan agar pemahaman anak sesuai harapan. Hal inilah yang dilakukan guru dalam memecahkan masalah penelitian.

\section{Pengertian Punarbhawa / Samsara}

Punarbawa disebut pula dengan istilah Samsara yang artinya kelahiran yang berulang-ulang ke dunia. Punarbawa merupakan salah satu keimanan dari Agama Hindu.
Keimana Agama Hindu dinamakan Panca Sradha, satu diantaranya adalah punarbhawa itu sendiri. Untuk menjelaskan pengertian Punarbhawa dari segi ilmu pengetahuan biasa, adalah tidak mungkin atau sangat sulit dipahami, karena punarbhawa merupakan suatu kepercayaan dalam ajaran Agama Hindu.

Punarhbawa hanya dapat diterima melalui keimanan atau kepercayaan, ini berarti dari luar rasio manusia. Walaupun demikian penjelasan punarbhawa itu akan diberikan batasan - batasan yang bersifat ratio dalam artian diangkat oleh pikira atau perasaan manusia. Dari segi asal kata, Punarbhawa berasal dari bahasa Sansekerta yaitu "punar dan bhawa". "Punar" artinya lagi, berulang - ulang, sedangkan "Bhawa" berarti menjadi, menjelma, lahir. Dengan demikian punarbhawa berarti kelahiran yang berulang ulang itu dapat di dunia ini, maupun didunia lain yang sifatnya lebih halus. Umpamanya seseorang dapat lahir di dunia ini, dapt pula di duni dewa, para jin dan sebagainya. Kelahiran berulang - ulang disebabkan oleh karmawasana setiap makhluk. Semua perbuatan yang dilakukan oleh seseorang dalam kehidupan akan berpahala dan pahala ini akan melekat pada suksma sarira yaitu badan halus. Lekatan pahala perbuatan itulah yang dinamakan karmawasana. Dalam badan manusia ada lima jenis badan yaitu : annamaya kosa, paranamaya kosa, manomaya kosa, wijanamaya kosa dan anandamaya kosa. Punarbhawa itu sesungguhnya adalah kelahiran badan halus bersama atma. Atma menurut kitab suci Hindu tidak dapat menjelma karena memenuhi alam semesta beserta isinya. 


\section{Prestasi Belajar}

Djamarah

mendefinisikan prestasi belajar sebagai hasil yang diperoleh berupa kesan-kesan yang mengakibatkan perubahan dalam diri individu sebagai hasil dari aktivitas dalam belajar.Kalau perubahan tingkah laku adalah tujuan yang mau dicapai dari aktivitas belajar, maka perubahan tingkah laku itulah salah satu indikator yang dijadikan pedoman untuk mengetahui kemajuan individu dalam segala hal yang diperolehnya di sekolah. Dengan kata lain prestasi belajar merupakan kemampuan-kemampuan yang dimiliki oleh siswa sebagai akibat perbuatan belajar atau setelah menerima pengalaman belajar, yang dapat dikatagorikan menjadi tiga ranah, yakni ranah kognitif, afektif, dan psikomotor.

Penjelasan para ahli tersebut mengandung hikmah bahwa yang dimaksud prestasi belajar adalah hasil yang dicapai seseorang sebagai individu setelah mengalami suatu proses belajar dalam waktu tertentu. Faktor-faktor yang dapat mempengaruhi prestasi belajar menurut Purwanto (2000: 102) antara lain: (1) faktor yang ada pada diri organisme itu sendiri yang dapat disebut faktor individual, seperti kematangan/pertumbuhan, kecerdasan, latihan, motivasi, dan faktor pribadi, (2) faktor yang ada diluar individu yang disebut faktor sosial., seperti faktor keluarga/keadaan rumah tangga, guru dan cara mengajamya, alat-alat yang dipergunakan dalam belajarmengajar, lingkungan dan kesempatan yang tersedia dan motivasi sosial. Dalam penelitian ini factor ke 2 yaitu factor yang dari luar seperti guru dan cara mengajarnya yang akan menentukan prestasi belajar siswa. Faktor keluarga antara lain: cara orang tua mendidik, relasi antara keluarga, suasana rumah tangga dan keadaan ekonomi keluarga. Faktor sekolah antara lain: metode mengajar, kurikulum, relasi guru dengan siswa, relasi siswa dengan siswa, disiplin sekolah, pelajaran dan waktu sekolah, standar pelajaran, keadaan gedung, metode belajar dan tugas rumah. Faktor masyarakat antara lain: kegiatan siswa dalam masyarakat, mass media, teman bergaul, bentuk kehidupan masyarakat. Peningkatan prestasi belajar yang penulis teliti dalam hal ini dipengaruhi oleh factor ekstern yaitu metode mengajar guru.

Dalam pembahasan ini akan dibicarakan mengenai prestasi belajar sebagai hasil penilaian dan pada pembahasan berikutnya akan dibicarakan pula prestasi belajar sebagai alat motivasi. Prestasi belajar sebagai hasil penilaian sudah dipahami.Namun demikian untuk mendapatkan pemahaman, perlu juga diketahui, bahwa penilaian adalah sebagai aktivitas dalam menentukan rendahnya prestasi belajar itu sendiri.

Dari uraian di atas, dapat disimpulkan bahwa prestasi belajar adalah hasil yang dicapai siswa setelah melakukan kegiatan belajar yang berbentuk angka sebagai simbol dari ketuntasan belajar bidang studi sejarah.Prestasi belajar ini sangat dipengaruhi oleh factor luar yaitu guru dan metode.Hal inilah yang menjadi titik perhatian peneliti di lapangan.

\section{HASIL PENELITIAN DAN PEMBAHASAN \\ Hasil Penelitian \\ Siklus I \\ Rencana Tindakan I \\ Perencanaan Meliputi:}


a) Guru selaku peneliti merencanakan untuk melakukan penelitian dari bulan. Juli sampai bulan Nopember pada semester I tahun 2016

b) Untuk memperdalam pemahaman tentang metode yang akan diterapkan, guru selaku peneliti melakukan pengkajian beberapa literatur yang sesuai dengan permasalahan yang akan diselesaikan. .

\section{Pelaksanaan Tindakan I.}

Tahap pendahuluan

Tahap inti

Siswa membaca dengan cermat uraian tentang pengertian Punarbhawa pada buku materi pembelajaran.

$>$ Guru memberikan paparan tentang pengertian Punarbhawa, siswa mendengarkan dengan seksama.

\section{Refleksi Siklus I}

Analisis kuantitatif Prestasi belajar siswa siklus I

Rata-rata (mean) dihitung

dengan: $\frac{\text { Jumlah nilai }}{\text { Jumlah siswa }}=\frac{3085 . .}{45 .}=68,55$

a. Median (titik tengahnya) dicari dengan mengurut data/nilai siswa dari yang terkecil sampai terbesar. Setelah diurut apabila jumlah data ganjil maka mediannya adalah data yang ditengah. Kalau jumlahnya genap maka dua data yang di tengah dijumlahkan dibagi 2 (dua). Untuk median yang diperoleh dari data siklus I dengan menggunakan cara tersebut adalah: 70

b. Modus (angka yang paling banyak/paling sering muncul) setelah diasccending/diurut angka tersebut adalah: 70

\section{Siklus II \\ Perencanaan}

Perencanaan meliputi:

a) Guru selaku peneliti merencanakan untuk melakukan penelitian dari bulan Juli . sampai bulan Nopember 2016 pada semester I

b) Guru selaku peneliti merencanakan untuk memperbaiki prestasi belajar Agama Hindu yang masih di bawah KKM memanfaatkan diskusi dan bercerita . Untuk memperdalam pemahaman tentang metode yang akan diterapkan, guru selaku peneliti melakukan pengkajian beberapa literatur yang sesuai dengan permasalahan yang akan diselesaikan.

c) Menyusun jadwal penelitian, materi, RPP, soal-soal sebagai instrumen untuk mengumpulkan data hasil penelitian.

\section{Pelaksanaan Tindakan II}

a. Sebelum memasuki ruangan kelas untuk memulai pelaksanaan tindakan pada siklus II ini guru selaku peneliti menyiapkan segala alat dan perlengkapan yang akan dibawa ke ruang kelas.

b. Sesampainya di kelas, guru selaku peneliti melaksanakan pembelajaran dengan pembelajaran pendahuluan yaitu: mengucapkan salam, melakukan absensi, memotivasi siswa agar giat belajar, melakukan apersepsi, menyampaikan tujuan pembelajaran serta cakupan materi yang sedang diajarkan.

Tahap pendahuluan

Guru mengawali pembelajaran dengan mengucapkan salam agama Hindu yakni Om Svastiastu, setelah 
mengucapkan salam guru mengajak siswa untuk melantunkan Gāyatri puja.

$>$ Guru mengajak siswa mengucapkan doa Dainika Upasana untuk memulai belajar. "Om Awignam Astu Namo Sidham" atau dainika upasana yang lain seperti guru puja, saraswati puja dan yang lainnya.

Tahap inti

$>$ Guru memberikan paparan secara singkat hubungan tampilan slide show power point yang berkaitan dengan pengertian punarbhawa sebagai bagian dari srada, siswa mendengarkan dengan seksama

> Guru memberikan paparan tentang pengertian punarbhawa, siswa mendengarkan dengan seksama.

\section{Penutup}

$>$ Guru mengajak siswa bersamasama membuat kesimpulan tentang pengertian punrabhawa sebagai bagia dari srada.

Melaksanakan penilaian dan refleksi dengan mengajukan pertanyaan atau tanggapan peserta didik dari kegiatan yang telah dilaksanakan sebagai bahan masukan untuk perbaikan langkah selanjutnya

Menyampaikan

rencana pembelajaran pada pertemuan berikutnya.

Pembelajaran ditutup dengan Salam Parama Santih "Om Santih-Santih Santih Om.

\section{Refleksi Siklus II}

Refleksi merupakan kajian secara menyeluruh tindakan yang telah dilakukan berdasarkan data yang telah terkumpul, kemudian dilakukan evaluasi guna menyempurnakan tindakan.Refleksi menyangkut analisis, sintesis, dan penilaian terhadap hasil pengamatan atas tindakan yang dilakukan (Hopkin, 1993 dalam Suharsimi Arikunto, Suhardjono, Supardi, 2006: 80).

Analisis kuantitatif Prestasi belajar siswa siklus II

a. Rata-rata (mean) dihitung dengan:

$\frac{\text { Jumlah nilai }}{\text { Jumlah siswa }}=\frac{.3430 .}{45 . .}=76,22$

b. Median (titik tengahnya) dicari dengan mengurut data/nilai siswa dari yang terkecil sampai terbesar. Setelah diurut apabila jumlah data ganjil maka mediannya adalah data yang ditengah. Kalau jumlahnya genap maka dua data yang di tengah dijumlahkan dibagi 2 (dua). Untuk median yang diperoleh dari data siklus I dengan menggunakan cara tersebut adalah: 75

c. Modus (angka yang paling banyak/paling sering muncul) setelah diasccending/diurut angka tersebut adalah: 70 .

\section{Pembahasan}

Pembahasan Hasil yang Diperoleh dari Siklus I Hasil tes prestasi belajar yang merupakan tes memforsir siswa untuk betul-betul dapat memahami apa yang sudah dipelajari. Nilai rata-rata siswa di siklus I sebesar 68,48 menunjukkan bahwa siswa setelah menguasai materi yang diajarkan walaupun belum begitu sempurna. Hasil ini menunjukkan peningkatan kemampuan siswa menguasai mata pelajaran agama hindu dan budi pekerti Apabila dibandingkan dengan nilai awal siswa sesuai data yang sudah disampaikan dalam analisis sebelumnya. 
Hasil tes prestasi belajar di siklus I telah menemukan efek utama bahwa penggunaan metode tertentu akan berpengaruh terhadap prestasi belajar siswa yang dalam hal ini adalah metode diskusi dan bercerita dengan hasil analisis metode pembelajaran yang dilakukan oleh Arends, (2004) bahwa model pengajaran langsung dapat meningkatkan hasil belajar kogntif atau pengetahuan deklaratif (mastery of-structured knowledge) dan meningkatkan suatu keterampilan atau pengetahuan prosedural (skill mastery). Kendala yang masih tersisa yang perlu dibahas adalah prestasi belajar yang dicapai pada siklus I ini belum memenuhi harapan sesuai dengan tuntutan KKM mata pelajaran agama Hindu dan budi pekerti di sekolah ini yaitu 70,00. Oleh karenanya upaya perbaikan lebih lanjut masih perlu diupayakan sehingga perlu dilakukan perencanaan yang lebih matang untuk siklus selanjutnya.

Pembahasan Hasil yang Diperoleh dari Siklus II.

Hasil yang diperoleh dari tes prestasi belajar di siklus II menunjukkan bahwa kemampuan siswa dalam mengikuti pelajaran sudah cukup baik. Ini terbukti dari rata-rata nilai siswa mencapai. 76,22 Hasil ini menunjukkan bahwa model pembelajaran diskusi dan bercerita telah berhasil meningkatkan prestasi belajar pendidikan agama hindu dan budi pekerti siswa.

Setelah dilakukan tindakan dalam dua siklus dapat dilihat perbandingan nilai rata-rata yang diperoleh, dimana pada awalnya nilai rata-rata siswa hanya 63,23 naik di siklus I menjadi 68,55 dan di siklus II naik menjadi 76,22. Kenaikan ini merupakan upaya maksimal yang peneliti laksanakan untuk meningkatkan prestasi belajar Agama Hindu dan Budi Pekerti siswa kelas IV

Semester I terutama meningkatkan mutu pendidikan di SD Negeri 4 Tonja.

\section{SIMPULAN}

Pemicu rendahnya prestasi belajar ada pada faktor model yang digunakan guru dalam proses pembelajaran.Untuk itu penggunaan model yang sifatnya konstruktivis sangat diperlukan. Dalam hal ini peneliti menerapkan modepembelajaran direct intruction sebagai solusi untuk memecahkan permasalahan yang ada.

Dari hasil refleksiyang telah disampaikan di Bab IV dan dengan melihat semua data yang telah dipaparkan, dapat disampaikan bahwa pencapaian tujuan penelitian di atas dapat dibuktikan dengan argumentasi sebagai berikut.

a) Dari data awal ada 23 siswa mendapat nilai dibawah KKM dan pada siklus I menurun menjadi 17 siswa dan siklus II tidak ada yang mendapat nilai di bawah KKM.

b) Nilai rata-rata awal 63,23 naik menjadi 68,55 . pada siklus I dan pada siklus II naik menjadi. 76,22

c) Dari data awal siswa yang tuntas hanya 22 orang sedang siklus I menjadi lebih banyak yaitu 28 orang siswa sedangkan siklus II 45 orang ini dapat dicapai karena 
Penerapan metode diskusi dan bercerita sangat efektif diterapkan dalam proses pembelajaran yang mengakibatkan siswa aktif, antusias dan dapat memahami materi yang diajarkan sehingga prestasi belajar. Agama Hindu dan Budi Pekerti siswa kelas IV semester I SD Negeri4 Tonja Tahun pelajaran 2016/2017 menjadi meningkat. Dari data tersebut diatas, maka simpulannya adalah penerapan metode diskusi dan bercerita dalam ajaran Punarbhawa sebagau bagian dari srada dapat meningkatkan prestasi belajar agama Hindu dan Budi Pekerti Siswa kelas IV Semester I SD Negeri 4 Tonja tahun Pelajaran 2016/2017.

\section{DAFTAR PUSTAKA}

Adnyana, Ida Bagus Putu. 2006. Jurnal Pendidikan dan Pengajaran Pengaruh Penerapan Strategi Pembelajaran Inovatif Pada Pelajaran Biologi Terhadap Kemampuan Berpikir Kreatif Siswa SMA. IKIP Negeri Singaraja, No. 3 TH. XXXIX Juli 2006.

Andriani, Umi dan Rani Nuraeni. 2008. Mencocok, Menempel dan Mewarnai. Jakarta: Erlangga for Kids.

Arikunto, Suharsimi; Suhardjono; Supardi. 2006. Penelitian Tindakan Kelas. Jakarta: PT Bumi Aksara. Daryanto. 1999.Evaluasi Pendidikan. Rineka Cipta: Jakarta.

Dimyati dan Mudjiono. 2001. Belajar dan Pembelajaran. Jakarta: Dirjen Dikti
Djamarah, Syaful Bahri. 2002. Prestasi Belajar dan Kompetensi Guru. Surabaya: Usaha Nasional.

Kardi S. dan Nur, 2000. Pengajaran Langsung. Penerbit: UnesaUniversity Press. Surabaya.

Kholil, Anwar. 2009. Model Pengajaran Langsung. Tersedia online http://anwarholil.blogspot.co $\mathrm{m} / 2009 / 01 /$ modelpengajaran-langsung.html.

Mulyasa,2011. Standar Kompetensi dan Sertifikasi Guru. Penerbit: PT Remaja Rosdakarya Bandung.

Purwanto, Ngalim. 1997. Psikologi Pendidikan. Bandung: Rosdakarya.

Sardiman, A.M. 1988. Interaksi dan Motivasi Belajar-Mengajar Pedoman bagi Guru dan Calon Guru. Jakarta: Rajawali Pers.

Slameto. 2003. Belajar dan Faktorfaktor yang Mempengaruhinya. Jakarta: Rineka Cipta.

Uno, B. Hamzah, et. al. 2001.Pengembangan Instrumen Untuk Penelitian. Jakarta: Delima Press.

Wina Sanjaya. 2006. Strategi Pembelajaran Berorientasi Standar Proses Pendidikan. Kencana Prenada Media: Jakarta.

Yamin, Martinis dan Maisah, 2009. Manajemen Pembelajaran Kelas, Strategi Meningkatkan Mutu Pembelajaran. Penerbit: Gaung Persada Press. Jakarta 